JMI Vol. 42 No. 1, Juni 2020

METAL INDONESIA

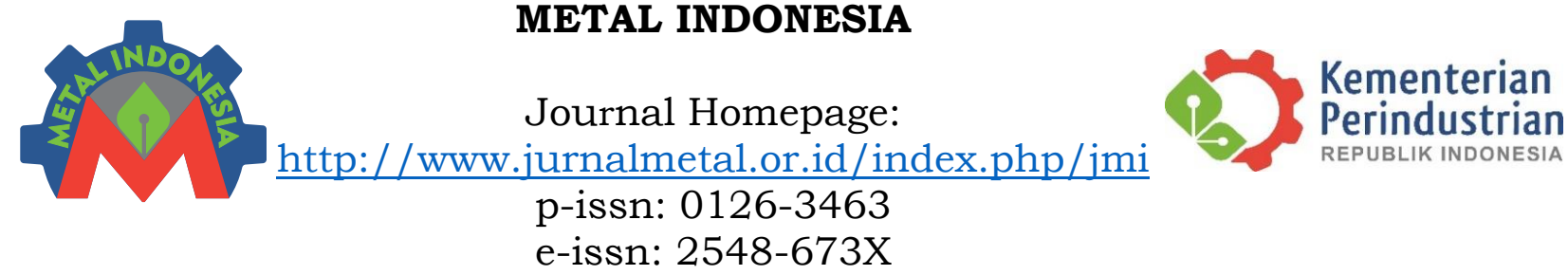

\title{
KARAKTERISTIK PENGARUH SUHU SINTERING TERHADAP KEKERASAN, POROSITAS DAN PENYUSUTAN RODA GIGI LURUS BERBAHAN SERBUK BESI
}

\section{CHARACTERISTICS OF EFFECT OF SINTERING TEMPERATURE ON HARDNESS, POROSITY AND SHRINKAGE OF SPUR GEAR MADE FROM IRON POWDER}

\author{
Hana Safira ${ }^{1}$, Slamet Sutjipto ${ }^{2}$,Haruman Wiranegara ${ }^{* 3}$ \\ 1,2 Jurusan Teknik Mesin,Politeknik Negeri Bandung, Bandung 40012 \\ ${ }^{3}$ Balai Besar Logam dan Mesin, Bandung 40135 \\ E-mail :3harumanw@gmail.com \\ *Kontributor Utama
}

\begin{abstract}
Abstrak
Roda gigi lurus merupakan jenis roda gigi yang paling umum digunakan sebagai komponen mesin. Serbuk yang digunakan pada penelitian ini merupakan serbuk besi (Fe) 100 mesh yang kemudian dikompaksi dengan gaya 8 ton dan di sintering pada beberapa variasi suhu yaitu 800, 900, 1000, 1100 dan $1200{ }^{\circ} \mathrm{C}$ yang diambil dari 0,5-0,8 titik cair (Tm) serbuk utama. Penelitian ini bertujuan untuk melihat karakteristik pengaruh suhu sintering pada kekerasan, porositas dan penyusutan roda gigi lurus berbahan serbuk besi (Fe). Waktu sintering dibuat konstan yaitu 60 menit. Beberapa pengujian dilakukan untuk dapat mencapai tujuan dari penelitian ini seperti perhitungan presentase penyusutan dan porositas, pengujian porositas pada struktur mikro dengan pengamatan metalografi, dan pengujian kekerasan mikro Vickers. Hasil penelitian menunjukkan bahwa seiring dengan naiknya suhu sintering maka penyusutan bertambah, porositas menurun dan nilai kekerasannya naik. Terdapat beberapa hasil penelitian yang tidak sesuai pada nilai porositas dan kekerasan produk. Hal tersebut dikarenakan beberapa faktor diantaranya sulit mencapai keseragaman densitas, preparasi material yang tidak sempurna dan pengaturan nilai kompaksi yang berbeda-beda pada setiap sampel karena mesin press mekanik yang digunakan.
\end{abstract}

Kata Kunci: Metalurgi serbuk, sintering, penyusutan, porositas, kekerasan

\begin{abstract}
Spur gears are the most common type of gears used as engine components. The powder used in this study was 100 mesh iron $(\mathrm{Fe})$ powder then compacted with a force of 8 tons and sintered at several temperature variations are 800,900, 1000, 1100 and $1200^{\circ} \mathrm{C}$ taken from 0.5-0.8 melting points (Tm) main powder. This study aims to look at the characteristics of the effect of sintering temperature on hardness, porosity and shrinkage of spur gears made from iron powder $(\mathrm{Fe})$. The sintering time is made constant at 60 minutes. Several tests were conducted to achieve the objectives of this study such as the calculation of the percentage of shrinkage and porosity, porosity testing on microstructure with metallographic observations, and micro hardness testing of vickers. The results show that as the sintering temperature increases, shrinkage increases, porosity decreases and the hardness value increases. There are some results of research that are not suitable for the porosity and hardness value of the product. This is due to several
\end{abstract}


factors including difficult to achieve uniformity of density, imperfect material preparation and different compacting value settings in each sample due to the mechanical press machine used.

Keywords: Powder metallurgy, sintering, shrinkage, porosity, hardness

\section{PENDAHULUAN}

Roda gigi merupakan komponen yang hampir selalu digunakan pada mesin seperti halnya baut dan mur. Terdapat banyak jenis roda gigi yang ada dan roda gigi lurus merupakan jenis yang paling umum digunakan. Beberapa metode komersial yang digunakan dalam memproduksi roda gigi, diantaranya adalah dengan proses pemesinan, pengecoran dan cetak tekan (Radzevich SP. Dudley's 2012).

Pembuatan roda gigi dengan pemesinan akan menghasilkan geram dan prosesnya memerlukan ketelitian tinggi sehingga dapat dihasilkan roda gigi kecepatan tinggi, awet, dengan tingkat kebisingan yang rendah. Roda gigi yang beroperasi lambat dan dalam keadaan terbuka dapat dibuat dengan pengecoran cetakpasir namun roda gigi yang dihasilkan tidak efisien dalam transmisi dayanya. Pengecoran cetak dan invesmen terbukti dapat menghasilkan roda gigi, namun bahan untuk roda gigi terbatas pada logam dan paduan dengan titik lebur yang rendah, akibatnya roda gigi tidak memiliki mutu keausan yang baik. Roda gigi yang sangat teliti dapat dihasilkan dengan proses cetak tekan, tetapi hanya dapat digunakan dalam membuat roda gigi tipis dari logam lembaran (Amstead BH 1995). Tahun 1800-an mulai dikembangkan metode metalurgi serbuk. Perkembangan pesat terjadi pada abad ke-20, dimana banyak komponenkomponen manufaktur kompleks dengan tingkat presisi yang tinggi diproduksi dengan proses metalurgi serbuk, termasuk roda gigi (Schey JA. 2009) .

Keuntungan digunakannya proses metalurgi serbuk ini yaitu produk yang dihasilkan akurat, tidak memerlukan pemesinan lanjut, ekonomis dalam produksi massal, tidak menghasilkan geram dan sifat khas produk seperti kekerasan, dan porositas dapat dikontrol (Schey JA. 2009)

Proses sinter merupakan salah satu proses penting yang ada pada metode metalurgi serbuk. Produk padatan mencapai kekuatan permanen, namun volumenya menyusut (densitasnya naik) sebagai akibat dari hilangnya sebagian besar pori- pori di antara partikel-partikel dalam proses sinter tersebut(Schey JA. 2009).

Karakteristik bahan yang dapat dipengaruhi oleh proses sinter diantaranya kekerasan, porositas dan penyusutan produk yang merupakan fokus penelitian ini. Dokumen hasil penelitian dibuat dalam bentuk grafik dan tabel sehingga dapat membantu dan memudahkan penentuan parameter dalam pembuatan roda gigi lurus yang sesuai kebutuhan.

\section{TINJAUAN PUSTAKA}

\section{Metalurgi Serbuk}

Metalurgi serbuk merupakan sebuah proses manufaktur dimana serbuk halus sebagai material utama akan dikompaksi dalam cetakan kemudian disinter dalam tungku pemanas. Terdapat 4 langkah utama dalam proses metalurgi serbuk, yaitu : (Höganäs 2013)

1. Produksi serbuk (powder manufacture),

2. Pencampuran (mixing or blending),

3. Penekanan (compaction) dan

4. Penyinteran (sintering).

Aliran proses metalurgi serbuk secara sederhana dapat dilihat pada Gambar 1. Tahapan kompaksi biasanya dilakukan pada suhu ruangan, sedangkan proses sintering biasanya dilakukan pada suhu tinggi dalam tekanan dan atmosfer terkontrol. Proses lebih lanjut biasanya diperlukan untuk mencapai spesial kriteria atau kepresisian produk.

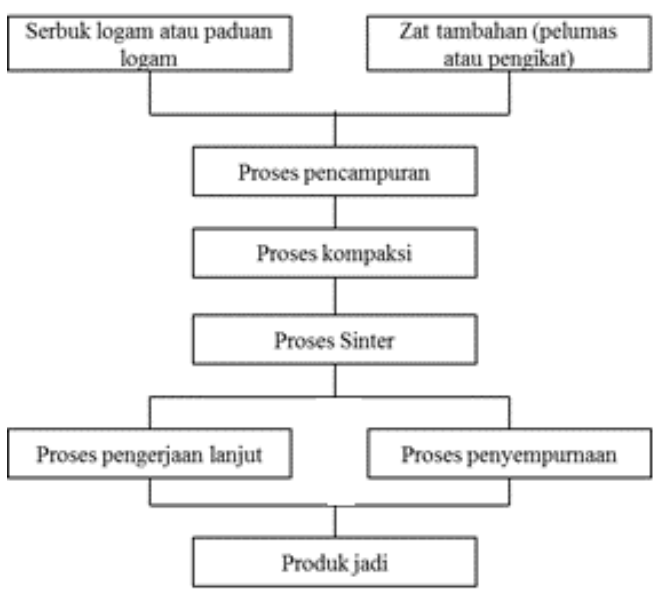

Gambar 1. Aliran proses metalurgi serbuk 


\section{Roda Gigi Lurus}

Roda gigi merupakan elemen mesin yang berfungsi mentransmisikan daya dan/atau gerakan putar dari satu poros ke poros yang lain (Amstead BH 1995). Roda gigi lurus dapat mentransmisikan daya pada poros yang sejajar atau pararel. Sistem roda gigi yang ada di seluruh dunia diberi nama sistem involut, karena profil dari giginya pada prinsipnya adalah kurva involut (Amstead BH 1995). Gambar 2 menunjukkan nomenklatur untuk roda gigi lurus involut.

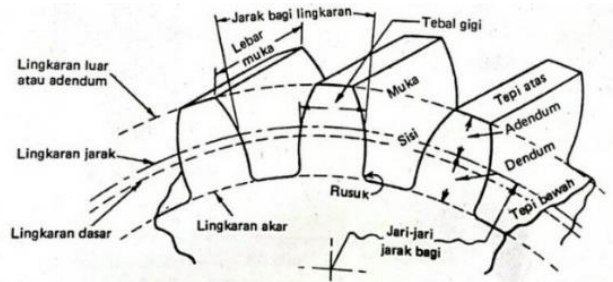

Gambar 2. Nomenklatur roda gigi lurus involut

\section{Karakteristik Material Fe}

Material utama yang digunakan pada penelitian ini sama dengan material yang digunakan pada penelitian sebelumnya. Yaitu serbuk besi yang diproduksi oleh Farco Chemical Supplies. Serbuk tersebut dihasilkan dengan cara atomisasi yang memiliki ukuran butiran serbuk 100 mesh dan berbentuk bulat. Berikut merupakan propertis fisik dan kimia dari serbuk besi:

Densitas pada $20^{\circ} \mathrm{C} \quad: 7,87 \mathrm{~g} / \mathrm{cm} 3$

Densitas pada lebur $\quad: 6,98 \mathrm{~g} / \mathrm{cm} 3$

Titik lebur $\quad: 1536^{\circ} \mathrm{C}$

Titik didih $: 3000 \mathrm{oC}$

Specific heat pada $20^{\circ} \mathrm{C}: 0,11 \mathrm{cal} / \mathrm{g} / \mathrm{oC}$

Heat of fusion $\quad: 65,5 \mathrm{cal} / \mathrm{g}$

Modulus elastisitas $\quad: 28,5 \times 103 \mathrm{Mpa}$

Kekerasan Vickers : $608 \mathrm{Mpa}$

Kekerasan Brinell : 490 Mpa (Zulkarnain MI 2013)

\section{METODE PENELITIAN}

Metodologi penelitian dibagi menjadi 4 yaitu pembuatan produk, perhitungan, pengujian, dan karakterisasi produk.

\section{Pembuatan Produk}

Tahap pembuatan produk yang berupa roda gigi lurus akan melalui beberapa tahapan proses yang dapat dilihat pada Gambar 3.

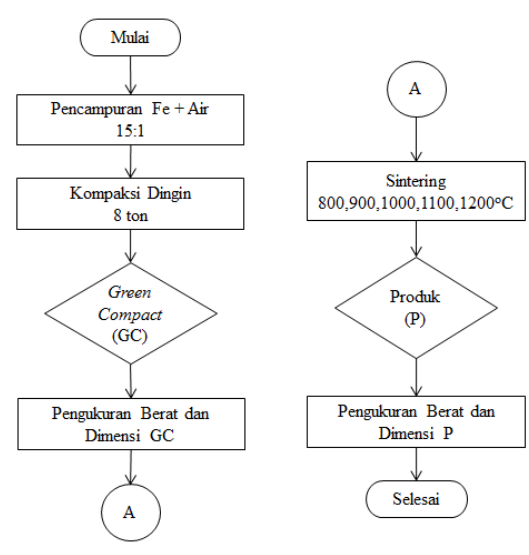

Gambar 3. Diagram alir pembuatan produk

Tahap pembuatan produk diawali dengan proses pencampuran material serbuk besi $(\mathrm{Fe})$ dan pengikat air dengan perbandingan 15:1 yang didapatkan dari hasil pre-study.

Proses kompaksi dilakukan menggunakan cetakan dengan penekan satu arah dimana gaya kompaksi yang diberikan yaitu 8 ton yang merupakan batas bawah daerah kerja yang dibatasi dengan perubahan rasio kompaksi secara signifikan (Nanditya A 2018). Proses kompaksi dilakukan pada temperatur ruang tanpa pemanasan menggunakan fasilitas mesin press mekanik "Compac" dengan kapasitas 10 ton.

Green compact dan produk jadi ditimbang menggunakan fasilitas timbangan elektrik "Teraoha DC-3000" dengan kapasitas $5 \mathrm{~kg}$. Sedangkan pengukuran dimensi tebal dilakukan secara langsung menggunakan alat ukur jangka sorong digital "MITUTOYO" dengan ketelitian $\pm 0,01 \mathrm{~mm}$.

Proses sinter dilakukan menggunakan fasilitas muffle furnace "Isuzu" dengan kapasitas $1500^{\circ} \mathrm{C}$. Karena keterbatasan alat, penyinteran tidak dilakukan pada keadaan vakum. Parameter penyinteran untuk setiap sampel yang dikerjakan dapat dilihat Tabel 1. Proses sinter yang dilakukan merujuk pada diagram perlakuan panas pada Gambar 4.

\section{Perhitungan}

Perhitungan Penyusutan

Besarnya nilai penyusutan dimensi tebal produk setelah proses sintering ditentukan dengan perbandingan seperti pada Persamaan 1.(Randal MN 1991) 
\%penyusutan tebal $=\frac{\mathrm{h}_{\mathrm{o}}-\mathrm{h}_{\mathrm{f}}}{\mathrm{h}_{\mathrm{o}}} \times 100 \%$ (1) dimana :

$\mathrm{h}_{\mathrm{o}} \quad=$ tebal sebelum sintering

$\mathrm{h}_{\mathrm{f}} \quad=$ tebal setelah sintering

Tabel 1. Parameter penyinteran tiap sampel

\begin{tabular}{|c|c|c|c|c|}
\hline $\begin{array}{c}\text { Sampel } \\
\text { ke- }\end{array}$ & $(\mathbf{a})$ & $(\mathbf{b})$ & $(\mathbf{c})$ & (d) \\
\hline 1 & $400^{\circ} \mathrm{C}$ & $\begin{array}{c}30 \\
\text { menit }\end{array}$ & $800^{\circ} \mathrm{C}$ & $\begin{array}{c}1 \\
\text { jam }\end{array}$ \\
\hline 2 & $450^{\circ} \mathrm{C}$ & $\begin{array}{c}30 \\
\text { menit }\end{array}$ & $900^{\circ} \mathrm{C}$ & $\begin{array}{c}1 \\
\text { jam }\end{array}$ \\
\hline 3 & $500^{\circ} \mathrm{C}$ & $\begin{array}{c}30 \\
\text { menit }\end{array}$ & $1000^{\circ} \mathrm{C}$ & $\begin{array}{c}1 \\
\text { jam }\end{array}$ \\
\hline 4 & $550^{\circ} \mathrm{C}$ & $\begin{array}{c}30 \\
\text { menit }\end{array}$ & $1100^{\circ} \mathrm{C}$ & $\begin{array}{c}1 \\
\text { jam }\end{array}$ \\
\hline 5 & $600^{\circ} \mathrm{C}$ & $\begin{array}{c}30 \\
\text { menit }\end{array}$ & $1200^{\circ} \mathrm{C}$ & $\begin{array}{c}1 \\
\text { jam }\end{array}$ \\
\hline
\end{tabular}

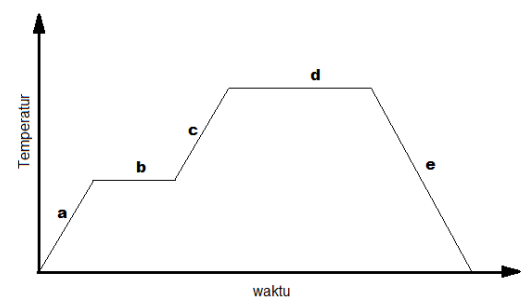

Gambar 4. Diagram perlakuan panas proses sinter

Keterangan :

a. Pemanasan awal: sampel dipanaskan dari suhu ruangan $22^{\circ} \mathrm{C}$ hingga mencapai 0,5 suhu penyinteran.

b. Waktu penahanan pemanasan awal: sampel ditahan pada temperatur pemanasan awal selama 30 menit, dengan tujuan sampel dan wadah menerima panas yang sama.

c. Temperatur penyinteran: sampel dipanaskan dari temperatur pemanasan awal ke temperatur penyinteran.

d. Waktu penahanan proses sinter: sampel ditahan pada suhu penyinteran selama 1 jam agar wadah dan sampel tersinter penuh dan merata.

e. Pendinginan: sampel dikeluarkan dari wadah dan didinginkan di udara terbuka sehingga kembali ke suhu ruang $22^{\circ} \mathrm{C}$.

Perhitungan Porositas

Nilai Porositas teoritis dihitung menggunakan teori Archimides sesuai dengan standar ASTM C373-88 (ASTM International 1999b). Besarnya nilai porositas dinyatakan dalam presentase yang menghubungkan antara volume pori terbuka terhadap volum benda keseluruhan dan dapat dihitung dengan Persamaan 2.

Presentase porositas $=\frac{W_{c}-W_{a}}{W_{c}-W_{b}} \times 100 \%$ (2) dimana :

$\mathrm{W}_{\mathrm{a}} \quad=$ berat sampel di udara

$\mathrm{W}_{\mathrm{b}} \quad=$ berat sampel dalam air

$\mathrm{W}_{\mathrm{c}}=$ berat sampel di udara setelah diangkat dari air

Pengukuran berat pada berbagai kondisi tersebut dilaksanakan menggunakan failitas neraca elektrik "KERN ABS" dengan kapasitas $220 \mathrm{~g}$ dan ketelitian 0,0001g. Pelaksanaan praktikum ini dilakukan di LAB Kimia POLBAN. ini digunakan sebagai input material yang akan di analisis dalam proses simulasi.

\section{Pengujian}

Pengujian Struktur Mikro

Pengujian struktur mikro dilakukan dengan metalografi untuk melihat porositas yang terjadi pada struktur mikro setiap sampel. Pemotongan sampel uji dilakukan pada arah melintang menggunakan fasilitas mesin "wire cut" untuk menghindari terjadinya efek panas akibat gesekan yang dapat mempengaruhi struktur mikro bahan.

Pengujian struktur mikro dilaksanakan di PT. Dirgantara Indonesia dan dilakukan tanpa proses pembakaran (etching) mengacu pada standar ASTM E3-95 (ASTM International 1999a). Perbesaran optik yang dilakukan sebesar 50 sampai $500 x$ dengan bantuan fasilitas mikroskop optik "NIKON".

\section{Pengujian Kekerasan Mikro Vickers}

Menurut DSN, nilai kekerasan mikro vickers didefinisikan sebagai hasil bagi beban tekan dengan beban dalam gram dengan luas penetrasi dalam milimeter persegi yang dihitung dari panjang diagonal rata-ratanya. Nilai kekerasan dapat langsung terbaca pada mesin atau dihitung menggunakan Persamaan 3.

$\mathrm{VHN}=(2 \mathrm{P} \operatorname{Sin}(\theta / 2)) / \mathrm{L}^{2}=(1.854 \mathrm{P}) / \mathrm{L}^{2} \ldots(3)$ dimana :

VHN = nilai kekerasan mikro vickers

$\mathrm{P} \quad=$ beban yang diterapkan, $\mathrm{g}$ 
$\mathrm{L}=$ panjang diagonal rata-rata, $\mu \mathrm{m}$

$\theta=$ sudut antara permukaan intan $\left(136^{\circ}\right)$

Pengujian kekerasan mikro vickers dilaksanakan di PT. Dirgantara Indonesia mengacu pada standar ASTM E384-17 (ASTM International 2017). Pengujian kekerasan mikro vickers ini dilakukan menggunakan fasilitas mesin "Zwick Roel" dengan kapasitas 10gf $\div 2 \mathrm{kgf}$.

Layout titik uji untuk pengujian kekerasan dapat dilihat pada Gambar 5 dimana pengujian dilakukan pada bagian paling luar roda gigi sampai ke bagian dalam profil roda gigi sesuai dengan standar AGMA 925-B03 (AGMA 2005).

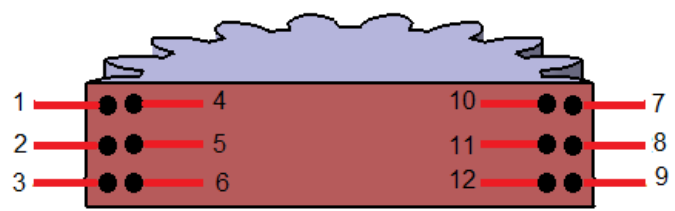

Gambar 5. Layout titik uji kekerasan pada sampel

\section{Karakterisasi Produk}

Sampel yang telah melakukan serangkaian tahap penelitian tersebut kemudian dikarakterisasi sehingga dapat diketahui karakteristik bahannya. Agar memudahkan, dibuatlah grafik pengaruh suhu sitering terhadap kekerasan, porositas dan penyusutan produk.

\section{HASIL DAN PEMBAHASAN}

Data hasil pengukuran berat tiap sampel diperoleh setelah melakukan proses penimbangan berat green compact dan produk jadi setelah sintering sebagaimana ditunjukkan pada Tabel 2.

Tabel 2. Berat Sampel

\begin{tabular}{|l|c|c|c|c|c|}
\hline Sampel Ke- & $\mathbf{1}$ & $\mathbf{2}$ & $\mathbf{3}$ & $\mathbf{4}$ & $\mathbf{5}$ \\
\hline Gaya kompaksi (ton) & 8 & 8 & 8 & 8 & 8 \\
\hline Suhu penyinteran $\left.\mathbf{(}^{\mathbf{}} \mathbf{C}\right)$ & 800 & 900 & 1000 & 1100 & 1200 \\
\hline $\begin{array}{l}\text { Berat serbuk sebelum } \\
\text { kompaksi (Kg) }\end{array}$ & 0,030 & 0,030 & 0,030 & 0,030 & 0,030 \\
\hline $\begin{array}{l}\text { Berat sampel setelah } \\
\text { kompaksi (Kg) }\end{array}$ & 0,030 & 0,030 & 0,028 & 0,028 & 0,030 \\
\hline $\begin{array}{l}\text { Berat sampel setelah } \\
\text { penyinteran (Kg) }\end{array}$ & 0,032 & 0,032 & 0,033 & 0,032 & 0,033 \\
\hline
\end{tabular}

Berdasarkan Tabel 2 dapat dilihat bahwa terjadi penambahan berat sampel setelah sintering akibat adanya oksidasi pada permukaan sampel. Hal ini dikarenakan sintering tidak dilakukan pada keadaan vakum dikarenakan keterbatasan alat.
Sampel kemudian dilakukan proses pembersihan mekanik dari oksidasi menggunakan amplas P1200. Sampel yang sudah bersih dari oksidasi tersebut kemudian akan diukur dimensi tebalnya. Proses pengukuran ini dilakukan untuk dapat mencari nilai presentase penyusutan yang terjadi setelah proses sintering dilakukan. Data hasil pengukuran dimensi tebal tersebut ditunjukkan pada Tabel 3 .

Tabel 3. Data hasil pengukuran dimensi tebal sampel

\begin{tabular}{|c|c|c|c|c|c|}
\hline Sampel ke- & $\mathbf{1}$ & $\mathbf{2}$ & $\mathbf{3}$ & $\mathbf{4}$ & $\mathbf{5}$ \\
\hline $\mathbf{h}_{\mathbf{0}} \mathbf{( m m )}$ & 7,10 & 7,14 & 6,42 & 6,66 & 7,03 \\
\hline $\mathbf{h}_{\mathbf{f}}(\mathbf{m m})$ & 6,62 & 6,59 & 5,87 & 6,03 & 5,83 \\
\hline \multicolumn{7}{|c}{} \\
\hline
\end{tabular}

Proses selanjutnya yaitu proses penimbangan berat sampel yang dilakukan pada keadaan kering, basah dan pada saat sampel diambil dari air. Proses penimbangan berat sampel ini dilakukan untuk dapat mencari nilai presentase porositas tiap sampel. Tabel 4 menunjukkan data hasil penimbangan berat sampel.

Tabel 4. Data hasil penimbangan berat sampel

\begin{tabular}{|l|c|c|c|c|c|}
\hline Sampel ke- & $\mathbf{1}$ & $\mathbf{2}$ & $\mathbf{3}$ & $\mathbf{4}$ & $\mathbf{5}$ \\
\hline $\mathbf{W}_{\mathbf{a}}(\mathbf{g})$ & 32,55 & 29,99 & 26,82 & 28,23 & 28,44 \\
\hline $\mathbf{W}_{\mathrm{b}}(\mathbf{g})$ & 32,46 & 29,95 & 26,74 & 27,95 & 26,42 \\
\hline $\mathbf{W}_{\mathrm{c}}(\mathbf{g})$ & 32,6 & 30,01 & 26,85 & 28,31 & 28,76 \\
\hline
\end{tabular}

$\mathrm{W}_{\mathrm{a}}$-------------- = berat sampel di udara

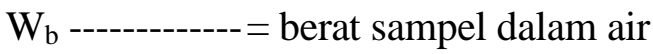

$\mathrm{W}_{\mathrm{c}}=$ berat sampel di udara setelah diangkat dari air

\section{Penyusutan Dimensi Tebal Produk}

Nilai penyusutan tebal produk yang terjadi setelah proses sintering dilakukan dihitung menggunakan Persamaan 3. Hasil dari perhitungan tersebut ditunjukkan pada Tabel 5

Tabel 5. Penyusutan tebal setiap sampel

\begin{tabular}{|c|c|c|c|}
\hline Sampel ke- & $\begin{array}{c}\text { Gaya kompaksi } \\
\text { (ton) }\end{array}$ & $\begin{array}{c}\text { Suhu sintering } \\
\left({ }^{\circ} \mathbf{C}\right)\end{array}$ & $\begin{array}{c}\text { Penyusutan tebal } \\
(\mathbf{\%})\end{array}$ \\
\hline $\mathbf{1}$ & 8 & 800 & 6,76 \\
\hline $\mathbf{2}$ & 8 & 900 & 7,7 \\
\hline $\mathbf{3}$ & 8 & 1000 & 8,57 \\
\hline $\mathbf{4}$ & 8 & 1100 & 9,45 \\
\hline $\mathbf{5}$ & 8 & 1200 & 17,07 \\
\hline
\end{tabular}




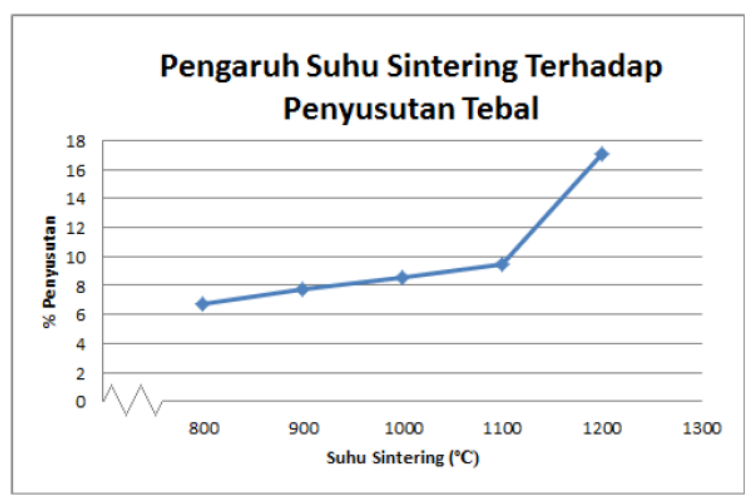

Gambar 6. Grafik pengaruh suhu sintering terhadap presentase penyusutan tebal

Gambar 6 menunjukkan bahwa terjadi pengaruh yang cukup signifikan terhadap penyusutan ketebalan roda gigi yang dihasilkan seiring dengan bertambahnya suhu penyinteran. Penyusutan ketebalan produk berbanding lurus dengan kenaikan suhu penyinteran. Sampel produk mengalami penyusutan dimensi tebal sebesar 6,76 17,07\% pada suhu sintering 800 $\sim 1200^{\circ} \mathrm{C}$. Kenaikan penyusutan terbesar terjadi pada sampel 5 yaitu pada suhupenyinteran 1200

${ }^{\circ} \mathrm{C}$. Angka penyusutan naik secara signifikan sebesar 7,62\% dari sampel 4 ke sampel 5. Hal ini dikarenakan terdapat perbedaan tebal green compact yang dihasilkan setelah kompaksi pada setiap sampel. Batas butir (void) pada sampel 5 lebih besar dibandingkan dengan sampel 4. Saat penyinteran dilakukan, ruang antar batas butir akan mengecil sehingga kerapatan antar partikel pun bertambah yang menyebabkan dimensi produk mengecil. Semakin tinggi temperatur penyinteran, semakin tinggi pula penyusutan suatu produk terjadi. Hal tersebutlah yang menyebabkan penyusutan terjadi secara signifikan dari sampel 4 ke sampel 5. Perbedaan penyusutan yang terjadi pada tiap sampel ini pun akan berpengaruh pada karakteristik bahan yang dihasilkan tiap sampel. Secara teoritis, semakin besar nilai penyusutan suatu produk maka densitasnya pun semakin naik yang menyebabkan porositas pada suatu produk akan berkurang.

\section{Porositas Produk}

Nilai presentase porositas tiap sampel dihitung menggunakan Persamaan 2 sehingga diperoleh hasil sebagaimana ditunjukkan pada Tabel 6.
Tabel 6. Nilai densitas dan porositas

\begin{tabular}{|c|c|c|c|}
\hline Sampel ke- & $\begin{array}{c}\text { Gaya kompaksi } \\
\text { (ton) }\end{array}$ & $\begin{array}{c}\text { Suhu penyinteran } \\
\left({ }^{\circ} \mathbf{C}\right)\end{array}$ & $\begin{array}{c}\text { Porositas } \\
(\mathbf{\%})\end{array}$ \\
\hline $\mathbf{1}$ & 8 & 800 & 35,71 \\
\hline $\mathbf{2}$ & 8 & 900 & 33,33 \\
\hline $\mathbf{3}$ & 8 & 1000 & 27,27 \\
\hline $\mathbf{4}$ & 8 & 1100 & 22,22 \\
\hline $\mathbf{5}$ & 8 & 1200 & 13,68 \\
\hline
\end{tabular}

Nilai yang didapat pada Tabel 6 selanjutnya dibuatkan grafik sebagaimana ditunjukkan pada Gambar 7 sehingga dapat dilihat grafik pengaruh suhu sintering terhadap presentase porositas tiap sampel.

Gambar 7 menunjukkan bahwa secara perhitungan teoritis, terjadi pengaruh yang cukup signifikan terhadap presentase porositas tiap sampel seiring dengan bertambahnya suhu penyinteran. Nilai porositas sampel produk pada penelitian ini turun dari $35,71 \%$ ke angka $13,68 \%$ selama penyinteran dilakukan pada suhu $800 \sim 1200^{\circ} \mathrm{C}$. Hal ini mengindikasikan bahwa semakin tinggi suhu penyinteran yang diberikan, maka presentase porositas pada sampel pun akan menurun. Pengaruh suhu penyinteran terhadap nilai porositas ini dikarenakan saat proses sinter dilakukan, produk akan mencapai ikatan permanen dikarenakan partikel penyusunnya telah beralgomerasi penuh. Akibatnya, batas butir antar partikel yang ada akan menurun yang menyebabkan terjadinya penyusutan dimensi produk sehingga densitasnya meningkat. Secara teoritis, nilai densitas berbanding terbalik dengan porositas. Semakin tinggi nilai densitas suatu produk, maka semakin rendah nilai porositasnya.

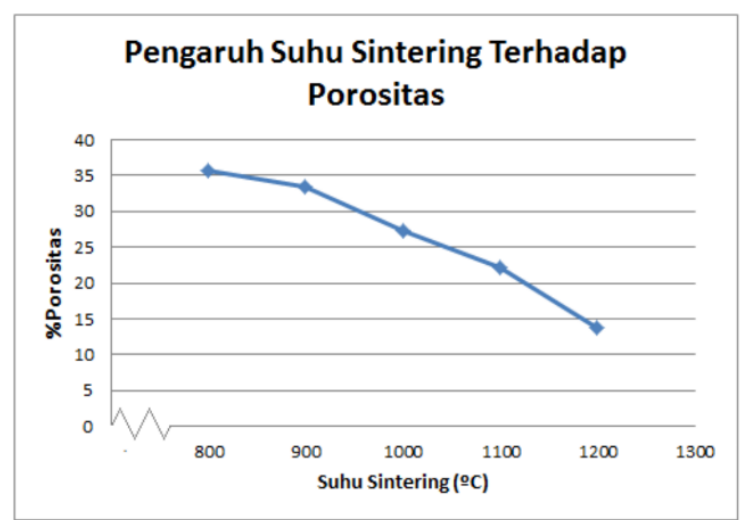

Gambar 7. Grafik Pengaruh Suhu Sintering Terhadap Presentase Porositas 
Pengujian metalografi kemudian dilakukan untuk melihat porositas produk pada arah melintang struktur mikronya. Hal ini dilakukan untuk membuktikan nilai presentase porositas yang didapatkan melalui percobaan Teori Archimides pada Tabel 6. Gambar 8 menunjukkan hasil pengujian metalografi yang telahdilakukan pada tiap sampel dengan perbesaran 100x.

Gambar 8 menunjukkan bahwa terdapat penurunan porositas pada struktur mikro sampel 1 sampai sampel 4 tetapi porositas terlihat meningkat pada struktur mikro sampel ke-5.
Sampel yang dinter pada suhu $800^{\circ} \mathrm{C}$ menunjukkan bahwa muncul formasi neckling antar partikel yang kemudian formasi neckling tersebut semakin membesar seiring dinaikkannya suhu penyinteran pada $900^{\circ} \mathrm{C}$ dan $1000^{\circ} \mathrm{C}$. Sampel yang disinter pada suhu $1100^{\circ} \mathrm{C}$ menunjukkan bahwa hasil pengamatan struktur mikronya terjadi penurunan porositas yang cukup signifikan.

Formasi neckling yang sebelumnya terjadi semakin melebar yang menyebabkan partikel-partikel penyusunnya sudah saling berikatan. Sampel yang disinter pada suhu $1200^{\circ} \mathrm{C}$

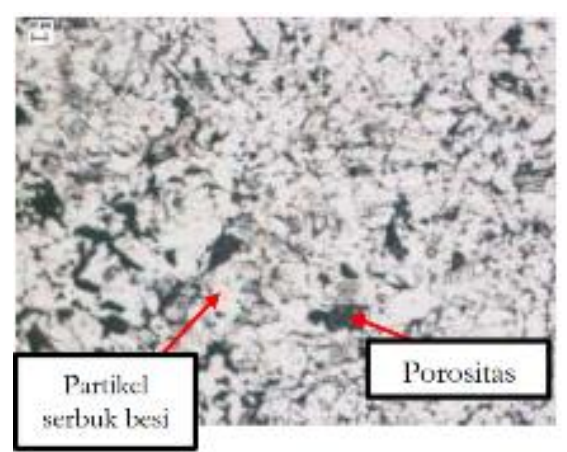

(a)

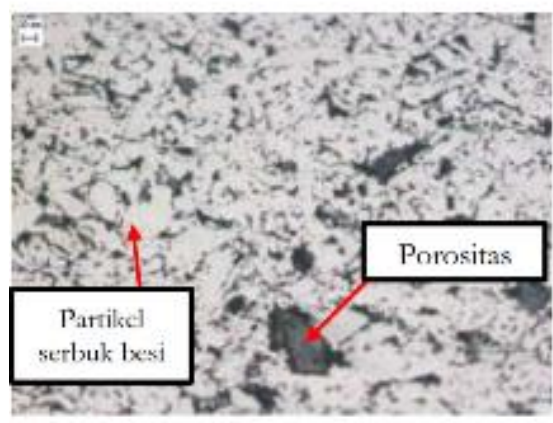

(c)

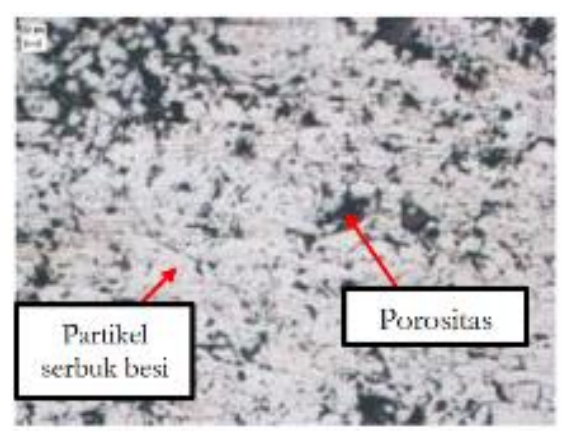

(b)

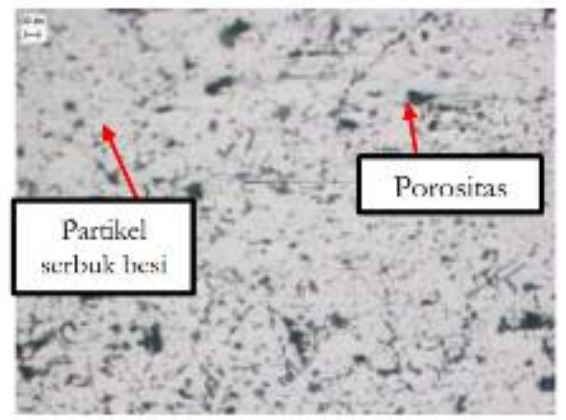

(d)

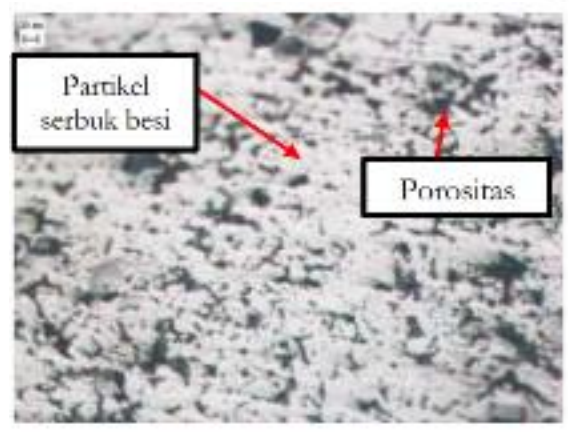

(e)

Gambar 8. Hasil Pengujian Metalografi Perbesaran 100x setelah sintering (a) $800^{\circ} \mathrm{C}$;(b) $900^{\circ} \mathrm{C}$ (c) $1000^{\circ} \mathrm{C}$; (d) $1100^{\circ} \mathrm{C}$; (e) $1200^{\circ} \mathrm{C}$ 
menunjukkan bahwa porositasnya bertambah jika dibandingkan dengan porositas pada sampel yang disintering $1100^{\circ} \mathrm{C}$. Adanya peningkatan porositas dari sampel 4 ke sampel 5 ini dikarenakan gaya kompaksi yang diberikan tidak merata pada setiap sampel. Tabel 7 menunjukkan bahwa terdapat perbedaan ketebalan green compact yang dihasilkan setelah proses kompaksi dilakukan pada tiap sampel. Gaya kompaksi lebih berpengaruh terhadap teknologi sintering jika dibangdingkan dengan suhu sintering (Nanditya A 2018). Hal ini lah yang menyebabkan pada pengamatan struktur mikro porositas sampel 5 memiliki porositas yang lebih besar dibandingkan sampel 4 walau pun suhu penyinteran yang diberikannya lebih tinggi.

\section{Kekerasan produk}

Pengujian kekerasan dilakukan sesuai standar pengujian kekerasan mikro vickers ASTM E384-17. Penentuan titik uji pada sampel dilakukan pada arah melintang sesuai standar AGMA 925-B03. Pada Gambar 4 menunjukkan titik sampel uji kekerasan mikro vickers.Hasil pengukuran panjang diagonal yang dihasilkan oleh indentor intan pada setiap titik dapat dilihat pada Tabel 7. Nilai L1 dan L2 dinyatakan dalam besaran $\mu \mathrm{m}$.

Tabel 7. Data hasil pengujian kekerasan mikro

\begin{tabular}{|c|c|c|c|c|c|c|c|c|c|c|}
\hline \multicolumn{11}{|c|}{ vicker } \\
\hline \multirow{2}{*}{$\begin{array}{c}\text { Titik } \\
\text { ke- }\end{array}$} & \multicolumn{2}{|c|}{$\# 1(\mu \mathrm{m})$} & \multicolumn{2}{|c|}{$\# 2(\mu \mathrm{m})$} & \multicolumn{2}{|c|}{$\# 3(\mu \mathrm{m})$} & \multicolumn{2}{|c|}{$\# 4(\mu \mathrm{m})$} & \multicolumn{2}{|c|}{$\# 5(\mu \mathrm{m})$} \\
\hline & L1 & L2 & L1 & L2 & L1 & L2 & L1 & L2 & L1 & L2 \\
\hline 1 & 12 & 11,4 & 12,3 & 12,3 & 10,9 & 11 & 10,1 & 10,3 & 11,2 & 10,4 \\
\hline 2 & 14,0 & 14,0 & 11,6 & 12,1 & 13,1 & 11,4 & 11,2 & 11,2 & 12,1 & 11,8 \\
\hline 3 & 10,8 & 10,4 & 12,9 & 12 & 11,9 & 12,6 & 11,6 & 12,1 & 11,6 & 12,7 \\
\hline 4 & 10,3 & 10, & 11,4 & 12,1 & 10,4 & 10,4 & 12,7 & 12,1 & 10,4 & 10,6 \\
\hline 5 & 14,6 & 15,9 & 12,9 & 13,1 & 12,1 & 12,7 & 10,8 & 10,8 & 11,6 & 11,8 \\
\hline 6 & 11,8 & 11,4 & 11,8 & 11,4 & 11,7 & 11,8 & 13,7 & 14,2 & 11,4 & 11,6 \\
\hline 7 & 13,5 & 14,6 & 11,4 & 11,4 & 5,9 & 5,8 & 10,3 & 10,8 & 10,4 & 11,2 \\
\hline 8 & 12,9 & 13,3 & 11 & 11,2 & 5,6 & 5,7 & 10,3 & 10,3 & 11,4 & 12,3 \\
\hline 9 & 13,8 & 14,8 & 12,5 & 13,1 & 5,9 & 6,1 & 11,6 & 12 & 11,2 & 11,4 \\
\hline 10 & 15,7 & 15,3 & 11,4 & 11 & 6,9 & 6,9 & 10,1 & 10,4 & 10,4 & 10,3 \\
\hline 11 & 12,0 & 11,6 & 10,8 & 11,2 & 11,6 & 11,8 & 10,1 & 10,4 & 11,6 & 11,2 \\
\hline 12 & 12,3 & 12,1 & 12,1 & 12 & 7,2 & 7,8 & 12,3 & 12,5 & 11,4 & 11,0 \\
\hline
\end{tabular}

Data hasil pengujian kekerasan mikro vickers pada Tabel 8 kemudian akan diolah dan dihitung menggunakan Persamaan 2 sehingga dapat diketahui nilai kekrasan mikro vickers pada setiap sampel. Nilai kekerasan mikro vickers tiap sampel tersebut disajikan pada Tabel 8
Tabel 8. Nilai kekerasan mikro vickers tiap sampel

\begin{tabular}{|c|c|c|c|c|c|}
\hline \multirow{2}{*}{$\begin{array}{c}\text { Titik } \\
\text { ke- }\end{array}$} & \multicolumn{4}{|c|}{ Nilai Kekerasan Mikro Vickers $($ HV/0.01) } \\
\cline { 2 - 6 } & $\mathbf{\# 1}$ & $\mathbf{\# 2}$ & $\mathbf{\# 3}$ & $\mathbf{\# 4}$ & $\mathbf{\# 5}$ \\
\hline $\mathbf{1}$ & 141 & 122 & 154 & 179 & 158 \\
\hline $\mathbf{2}$ & 94 & 132 & 124 & 148 & 130 \\
\hline $\mathbf{3}$ & 164 & 120 & 124 & 132 & 126 \\
\hline $\mathbf{4}$ & 179 & 134 & 171 & 120 & 167 \\
\hline $\mathbf{5}$ & 80 & 110 & 121 & 158 & 136 \\
\hline $\mathbf{6}$ & 138 & 138 & 135 & 96 & 141 \\
\hline $\mathbf{7}$ & 94 & 143 & 536 & 167 & 158 \\
\hline $\mathbf{8}$ & 108 & 150 & 581 & 176 & 132 \\
\hline $\mathbf{9}$ & 91 & 113 & 511 & 134 & 145 \\
\hline $\mathbf{1 0}$ & 77 & 148 & 393 & 176 & 173 \\
\hline $\mathbf{1 1}$ & 134 & 153 & 136 & 176 & 143 \\
\hline $\mathbf{1 2}$ & 124 & 129 & 327 & 120 & 148 \\
\hline$\overline{\mathbf{X}}$ & $\mathbf{1 1 8 , 6 6 7}$ & $\mathbf{1 3 2 , 6 6 7}$ & $\mathbf{2 7 6 , 0 8 3}$ & $\mathbf{1 4 8 , 5}$ & $\mathbf{1 4 6 , 4 1 7}$ \\
\hline
\end{tabular}

Nilai kekerasan mikro vickers yang ditunjukkan Tabel 8 tersebut nilainya sangat fluktuatif. Data pada Tabel 8 kemudian diolah dalam bentuk grafik sehingga dapat diketahui nilai kekerasan mikro vickers tiap sampel pada arah melintang. Gambar 9 menunjukkan grafik nilai kekerasan tiap sampel.

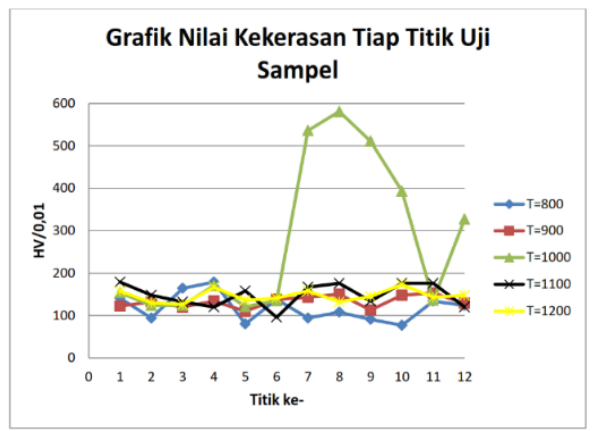

Gambar 9. Grafik nilai kekerasan pada tiap titik uji Sampel

Grafik nilai kekerasan yang dihasilkan pada tiap titik uji yang disinter pada berbagai variabel suhu ditujukkan pada Gambar 9 Secara teoritik, karena cetakan yang digunakan merupakan cetakan dengan sistem pendesak tunggal, maka densitas produk akan padat di bagian permukaan sampel uji yaitu pada titik 1, 4, 7 dan 10. Kekerasan di setiap titik uji nilainya fluktuatif. Hal ini menunjukkan bahwa pada sampel berbentuk roda gigi yang dihasilkan, densitas sampel tidak tersebar merata. Nilai rata- 
rata kekerasan mikro vickers pada sampel 3 memiliki nilai sebesar 276,083 HV/0,01 dimana pada titik ke 7, 8, 9, 10 dan 12 merupakan titik dimana nilai kekerasan mikro vickers sampel 3 menunjukkan angka yang sangat tinggi dibandingkan dengan titik yang lain. Selain karena densitas yang tidak merata pada sampel uji, nilai kekerasan tiap titik uji yang fluktuatif paada sampel ini dapat terjadi karena beberapa faktor diantaranya:

1. Penempatan indentor yang tidak merata saat melakukan pengujian kekerasan mikro vickers sehingga menimbulkan cacat jejak indentor. Hal ini dapat disebabkan karena preparasi material yang tidak sempurna.

2. Saat melakukan proses kompaksi, pengaturan yang dilakukan tidak sama untuk semua sampel. Akibatnya, green compact hasil kompaksi memiliki ketebalan yang berbedabeda tiap sampelnya yang mengindikasikan bahwa densitas tiap green compact berbeda tiap sampel. Hal ini dikarenakan mesin untuk kompaksi yang digunakan berbasis mekanik sehingga kemungkinan diberikannya gaya yang tidak merata pada setiap sampel sangatlah besar. Pengaruh suhu sintering terhadap nilai kekerasan berbanding terbalik dengan pengaruh suhu sintering terhadap porositas. Secara teoritis, semakin kecil nilai porositas suatu produk maka kekerasannya akan bertambah. Nilai rata-rata kekerasan tiap sampel yang ada pada Tabel 8 kemudian diolah dalam bentuk grafik untuk melihat pengaruh suhu sintering terhadap nilai kekerasan produk yang dapat dilihat pada Gambar 10.

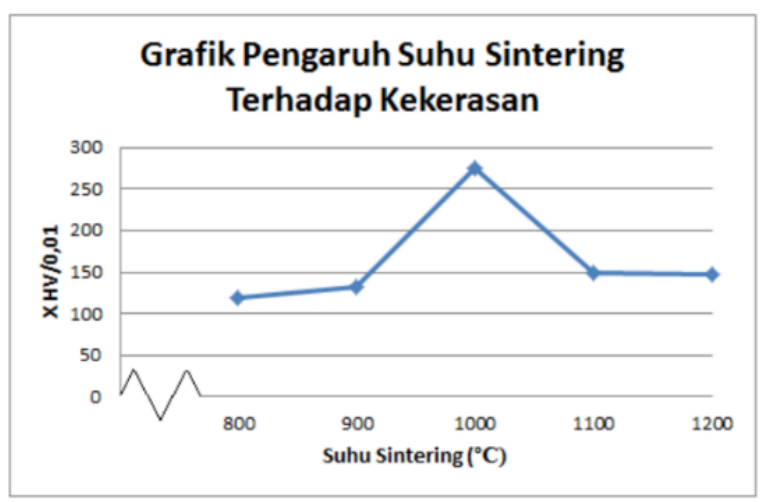

Gambar 10. Grafik pengaruh suhu sintering terhadap Kekerasan
Nilai rata-rata kekerasan mikro vickers dari sampel 1 ke sampel 2 meningkat sebesar 14 $\mathrm{HV} / 0,01$. Nilai rata-rata kekerasan mikro vickers dari sampel 4 ke sampel 5 menurun sebesar 2,083 HV/0,01. Nilai yang didapatkan tersebut berbanding lurus dengan porositas pada struktur mikro tiap sampel. Hal ini berarti bahwa porositas produk akan mempengaruhi nilai kekerasannya, secara umum dari hasil pengujian semakin rendah nilai porositas suatu produk maka nilai kekerasannya semakin tinggi, adapun ketidaksinkronan pada sample 3 dan 5 hal ini diakibatkan dari kelemahan pengujian yang menyebabkan kesalahan baca atau hasil.

\section{KESIMPULAN DAN SARAN}

Berdasarkan hasil penelitian ini, maka dapat disimpulkan bahwa terdapat pengaruh suhu sintering terhadap karakteristik bahan berupa kekerasan, porositas dan penyusutan roda gigi berbahan serbuk besi. Ketiga karakteristik bahan tersebut memiliki hubungan dan saling mempengaruhi satu sama lain. Penyusutan produk akan bertambah seiring dengan naiknya suhu sintering. Nilai penyusutan yang terjadi sebesar 6,76 17,07\% pada pemanasan suhu penyinteran $800 \sim 1200^{\circ} \mathrm{C}$. Akibat penyusutan yang terjadi, densitas produk pun bertambah sehingga nilai porositasnya menurun dari angka $35,71 \%$ ke angka $13,68 \%$ namun setelah dilakukan pengujian metalografi nilai porositas terlihat bertambah pada sampel ke-5. Semakin rendah nilai porositas suatu produk maka nilai kekerasannya semakin tinggi. Nilai kekerasan dari sampel 1 ke sampel 2 naik sebesar 14 HV/0,01 dan turun dari sampel 4 ke sampel 5 sebesar 2,083 HV/0,01 sedangkan nilai kekerasan yang terjadi pada sampel 3 hasilnya jauh diatas nilai kekerasan sampel yang lain, yaitu sebesar 276,083 HV/0,01. Masih terdapatnya beberapa nilai karakteristik bahan yang tidak sesuai secara teoritis ini terjadi karena beberapa faktor diantaranya pertama, kesalahan penempatan indentor saat pengujian karena preparasi material yang tidak sempurna.

Kedua, terdapat perbedaan pengaturan yang dilakukan pada saat proses kompaksi sehingga gaya yang diterima setiap sampel berbeda dan menyebabkan densitas setiap sampel tidak merata. 


\section{DAFTAR PUSTAKA}

AGMA. 2005. American Gear Manufacturers Association. Metallurgical Specifications for Steel Gearing. Amerika: AGMA.

Amstead BH. 1995. Teknologi Mekanik Jilid 2 Edisi 7. Jakarta: Erlangga.

ASTM International. 1999a. Standard Practice for Apparent Specific Gravity of Fired Whiteware Products; (E3-95).

- 1999b. Standard Test Method for Water Absorption, Bulk Density, Apparent Porosity, and Apparent Specific Gravity of Fired Whiteware Products ;(C373-88).

—. 2017. Standard Test Method for Microindentation Hardness of Materials;(E384-17).

Höganäs. 2013. Powder Metallurgy Handbook Höganäs' Handbook 2 - Production of Sintered Components. Höganäs HB.

Nanditya A. 2018. "Optimasi Proses Sintering Baja Karbon $0.3 \%$ C Terhadap Penyusutan Ketebalan Minimum Menggunakan Metode Taguchi." POLBAN.

Radzevich SP. Dudley's. 2012. Handbook of Practical Gear Desain and Manufacture. Boca Raton: CRC Press.

Randal MN. 1991. Fundamental of Sintering Engineered Material Handbook.

Schey JA. 2009. Proses Manufaktur Introduction to Manufacturing Processes. Yogyakarta: Andi.

Zulkarnain MI, Nopiandi R. 2013. "Rancang Bangun Cetakan Roda Gigi Lurus Berbasis Metalurgi Serbuk Tanpa Lubang Poros." POLBAN. 